\title{
Assessment of the project teams' communication skills in the automotive industry
}

doi:10.2478/mape-2019-0061

Date of submission to the Editor: 07/2018

Date of acceptance by the Editor: $08 / 2018$

MAPE 2019, volume 2, issue 1, pp. 624-632

\author{
Adam Górniak \\ Adam Górniak Consulting Company, Poland \\ Katarzyna Midor \\ ORCID ID: 0000-0001-5680-7354 \\ Jan Kaźmierczak \\ ORCID ID: 0000-0002-2459-470X \\ Silesian University of Technology, Poland
}

\section{INTRODUCTION}

Implementation of a new product in serial production is a very important element in the company's functioning. A successfully executed implementation project makes it possible to accept further production orders. The further fate of the plant and its related consequences depend on whether it is well carried out (Spałek, 2019). The result of implementation project is a product compliant with the order and coming from a stable production process, which is to give the customer a basis for consent to serial supply of this product in the following years (Grudzewski, 2004, Karaszewski et al., 2013, Plka et al., 2017).

The automotive industry is one of the most important in Poland, taking into account the economic turnover, where according to Automotivesuppliers.pl, the industry magazine employs about 280 thousand workers, nearly 1,400 business entities participate, and the value of sold production is about PLN 150 billion (Owczarzak, 2016).

The method or standard, according to which an implementation project is carried out in the automotive industry, combines two elements. The first one consists of issues typical for project management, such as resources, budget and implementation time. The second element concerns the issue of product quality. The implemented project is to ensure the required and stable quality of the product during the commissioning of production line and throughout the entire duration of contract for the supply of parts. Both elements, i.e. design and quality, have been included in the definition anticipating product quality planning (Górniak et al., 2017, Kaźmierczak et al., 2018). Since the automotive industry applies its own design procedures, they are issued in the form of a manual in force in a given manufacturing group. One of the most frequently used is Advanced Product Quality Planning (Chrysler et al., 2008) issued by Automotive Industry Action Group (AIAG), with its registered office in Michigan, United States.

According to the authors, there is a tendency to protect against risk during projects in the automotive industry by raising organizational, reporting and formal requirements 
for suppliers. The question arises here as to the characteristics of development direction of these requirements. Would an even stronger formalization of procedures bring tangible benefits? The authors of this paper believe that apart from formal and supervisory elements, no less important issues during the project implementation are the involvement, cooperation and communication of people engaged in the project. Efficient, open communication and willingness to cooperate between partners in the supply chain largely determine the efficiency of the entire supply chain.

\section{COMMUNICATION OF PROJECT TEAMS}

Manufacturers of cars and complex subassemblies have been working for years according to the established design and implementation standards of new products for serial production. A great emphasis is placed on the formal side. Forms must be completed, trial and serial parts produced on time and in satisfactory quality. Furthermore, the supplier must prove that has sufficient resources to achieve these objectives. This is what customers check during system, product, process and potential audits. However, it can happen, as shown by the frequent vehicle failures at service stations, that despite the formal approval of parts from the supplier, despite confirmation of the design and production capacity, defective parts or components are assembled in cars and distributed to the market. Why does this happen? The answer can often be found not in the forms, manuals or procedures, but in the way the project teams communicate and cooperate with each other and with other organizations, e.g. customer - supplier. Typical errors in corporate communication are given by WojtaśJakubowska (Wojtaś-Jakubowska, 2018):

- One-sided communication instead of two-sided communication.

- The client communicates to the supplier and the project management communicates to the project team members. Most often it is the client who presents requirements and expects the supplier to fulfil them without asking unnecessary questions and that will not have to deal with design modifications taking into account the specificity of supplier's product / manufacturing process. The same applies inside the design teams, their members are to provide the completed forms on time. Therefore, any discussions or doubts of a substantive nature are an unnecessary slowing down of work.

- Silencing employees' opinions.

- It is the management who knows best how a project should be run. Suggestions from employees are silenced as such that can lead to going beyond the standard of project management and

- Customer portal or internal portal of an organization is not directed to listening and adapting to the needs of its users (user-experience).

Often we are dealing with an attitude such as "this is our portal and it has to be filled correctly", regardless of whether it is useful or not. It often turns out that employees check the positions there as implemented, and the actual communication takes place through e-mails. It happens, what is worse, that the supplier does not fully understand what the customer expects, and filling out the items in the web portal not only does not facilitate communication, but on the contrary is just another additional obligation in addition to the production of correct parts and performing production and quality analyses. An analytical module to verify which tools and bookmarks are most often used by employees, which are omitted, and which are filled in with the highest number 
of errors, could be helpful here.

However, it is necessary to remember that even the most flexible, open and multidirectional communication will not ensure success of the implementation team on its own. It is also necessary, as APQP and MLA standards indicate, to have appropriate competences, understood as knowledge and rights of team members. Following the formal path, it is enough for a team member to undergo appropriate training or to have a work experience related to their competences. This is mentioned in the APQP manual (Chrysler et al., 2008) in the section Product Quality Planning Principles, subsections Team Organization and Training. It is mentioned there that the project team consists of representatives of various departments and specialties of the so-called cross-functional team, e.g. from technical, technological, production, material, purchasing, and not only from the quality department and new start-ups. Moreover, it points out that the success of anticipating product quality planning depends on an effective training programme in the area of specialist knowledge for a given position and quality, related to the impact of work on particular production stages and expanding the range of skills, as well as meeting formalized and nonformalized customer requirements. The VDA refers to this in the Product Creation, Maturity Level Assurance manual when discussing Level 2, where the supplier nomination process and the formation of project teams are described. However, it is necessary to add a reservation resulting from the research results carried out by Cindy McCauley (Midor, et al., 2017), developing the work of Lombardo and Eichinger, that it is important not only to select team members from various departments related to the implementation in terms of substantive competencies, but also in terms of ability to cooperate (cooperation) and to assign tasks to them in accordance with their experience, taking into account the element of personal development (Matuszak, et al., 2011, Klincewicz, 2016, Molenda, et al., 2018).

\section{RESEARCH METHOD}

In this paper, the authors used a survey, which was carried out with the use of a tool such as questionnaire form. The survey was one-off and anonymous. The questionnaire was used to check the perception of communication and cooperation skills by the project team members in the automotive industry.

The criterion for selection of respondents was employment in plants producing car parts for OEMs and membership of project teams. The survey involved volunteers. It was conducted in seven production plants, suppliers of components for the serial production of passenger cars from Silesia, Lower Silesia and Lubusz Voivodships. Twenty-seven managers and specialists delegated to implementation projects took part in it. The questionnaire included 14 questions. 4 questions were open-ended, allowing the respondent complete freedom of speech and 10 closed questions of a disjunctive nature allowing respondents to choose only one answer. The survey was conducted via the Google web platform.

\section{ANALYSIS OF RESPONSES OBTAINED IN THE SURVEY}

The survey questions that were included in the questionnaire concerning identification of strengths/weaknesses of the project team in the areas of communication and cooperation in the automotive industry were presented in Table 1. 
Table 1

Questionnaire on the work of project team

No.

\section{Question}

1 In which project do you participate? Describe your project and its objective.

Do you know your place in this project and your responsibility?

2 a. Fully

b. Partly

c. To a minor degree

In which field do you receive the most support or is the most helpful?

a. Customer contact

b. Simplicity and unambiguity of the requirements imposed on you

c. Support for the project team

d. Access to necessary data

3 e. Management support, including available resources

f. Your knowledge of the subject matter

g. Knowledge and experience of the team members

h. Innovativeness and advancement of the structure

i. Awareness of the project objectives and assumptions

j. Others

Scope of work related to which field of work do you find most difficult?

a. Customer contact

b. Simplicity and unambiguity of the requirements imposed on you

c. Support for the project team

d. Access to necessary data

4 e. Management support, including available resources

f. Your knowledge of the subject matter

g. Knowledge and experience of the team members

h. Innovativeness and advancement of the structure

i. Awareness of the project objectives and assumptions

j. Others

What does the information flow in the project team look like from your point of view?

a. Very good

5 b. Good

c. Enough

d. Poorly

e. Very bad

Are the data received from others sufficient?

a. Yes/b. No

7 Do you provide others with the data they need right away, without a hurry?

a. Yes/b. No

How do the requirements allow you to use your existing knowledge in the project?

a. I use it fully

8 b. I use it partially

c. I use it occasionally

d. I hardly use it at all

Guided by your intuition and knowledge of the project you have, how do you assess the chances for implementation of the project in assumed quality?

a. Almost certain

b. Probable

c. Unlikely

d. Impossible

10 What one thing would you ask the project team members to do in order to improve the team performance?

11 What did you notice in other team members, worth borrowing, that might have an impact on the project implementation?

12 Do you want to apply it for yourself?

a. Yes/b. No

13 What did you observe outside the project team that was worth borrowing (method of working, communication, type of planning, etc.)?

14 Will you propose this for use in your team? a. Yes/b. No

Source: (Górniak, 2019). 
The analysis of obtained answers by the respondents was presented below with reference to each question included in the survey.

Question 1 was aimed to introduce the respondents to survey mode and direct their attention to a specific implementation project in order to avoid generalizations and wishful thinking in the answers to subsequent survey questions. Therefore, its content is not important for the survey, except if no answer is given, but it did not take place in the survey.

Question 2 concerned the knowledge of respondent's responsibility in a given project. The question was answered by $81.5 \%$ of respondents that they fully knew their scope of responsibility, $18.5 \%$ that they knew it partially. Nobody answered that they knew it only to a small extent. Therefore, it can be concluded that the engineers working in project teams are aware of the responsibility for the task entrusted to them.

Question 3 asked the respondents to indicate which of the above mentioned areas they receive the most support in project implementation. The answers to this question show a strong dispersion of answers (Fig. 1.).

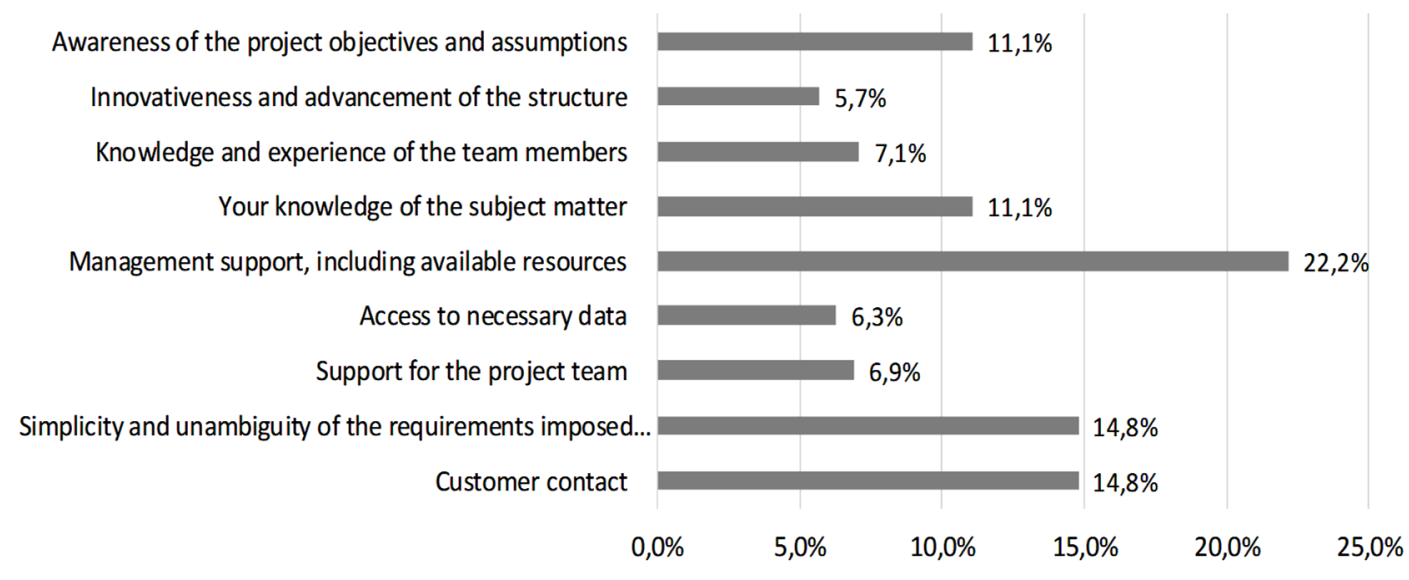

Fig. 1 Diagram showing areas facilitating the execution of project tasks

Indication of $22.2 \%$ for the management and resources available by them as the strongest factor facilitating the project implementation, only confirms what is the management's responsibility according to ISO 9001 and APQP.

Question 4 concerned the identification of areas which cause most difficulties for the respondents in project implementation. Most often it was the problem of availability of necessary data $-40.7 \%$. The answer concerning the knowledge and experience of team members reached $18.5 \%$, and the answer concerning the customer contact $14.8 \%$. Other answers were chosen much less frequently (Fig. 2). The answers obtained in this question generally indicate problems related to internal and external communication of the project team.

Question 5 asked the respondents to indicate what the information flow in the project team looks like from their point of view. "Sufficient" answers were marked $51.9 \%$, "good" answers $29.6 \%$. However, "bad" answer was given in $14.8 \%$.

Question 6 asked "Are the data received from others sufficient?" - 63\% of respondents chose "no", which probably means that they are forced to ask for the necessary information. However, in reply to question 7 "Do you provide others with the data they need right away, without a hurry?" $-88.9 \%$ of answers were "yes", which 
leads to conclusion that in the vast majority of respondents perceive themselves as solid, i.e. team members who follow the rules of conduct in the project and are willing to cooperate.

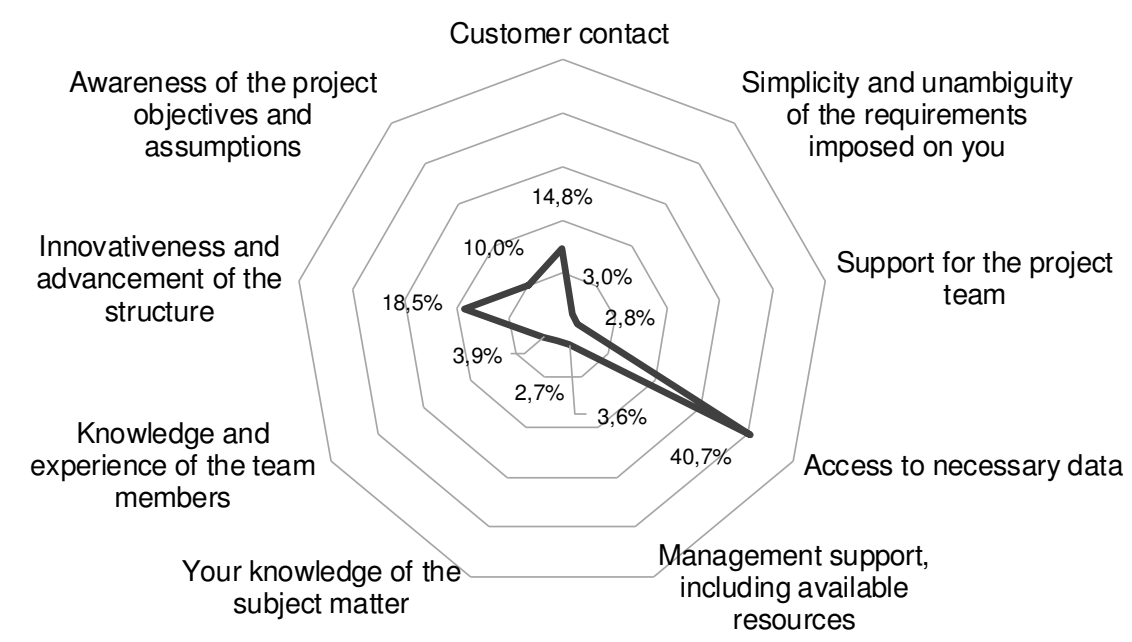

Fig. 2 Diagram showing areas hindering the execution of project tasks

Question 8 asked the respondents to what extent the requirements allow them to use their existing knowledge in the project. $63 \%$ of respondents said that they use it fully and $33.3 \%$ that they use it partially. Less than $4 \%$ of respondents answered that they used their knowledge only occasionally during projects. Obtained answers suggest that the key to selecting project team members is the knowledge and competences of the staff.

Question 9 concerned the question whether the respondent had a chance to implement the project. $51.9 \%$ chose "probable" and "almost certain" $-40.7 \%$. Just over $7 \%$ indicated "unlikely". Nobody chose the "impossible" answer. Obtained answers were shown in Figure 3.

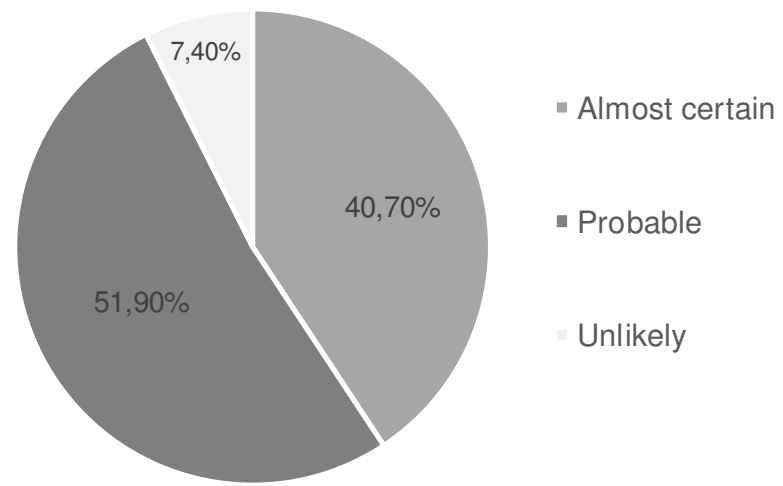

Fig. 3 Diagram of estimated chances for timely implementation of the project

Question 10 was intended to provide an opportunity to clarify the views expressed in previous answers. Respondents did not have the answers indicated here to choose from, they entered their own text. On this basis, four thematic groups were distinguished, most frequently indicated by the respondents. These include:

- $41 \%$ would improve communication and cooperation,

- $20 \%$ would improve the timeliness of providing data, 
- remaining opinions concerned support from others, creativity,

- there were also opinions that they did not see the need for improvement.

Question 11 asked the respondents "What did you notice in other team members, worth borrowing, that might have an impact on the project implementation?" Respondents' answers to this question were divided into five thematic groups:

- $22 \%$ indicated that there was nothing to imitate in others,

- $15 \%$ indicated commitment,

- $11 \%$ chose openness and communication,

- $11 \%$ chose self-control and tranquility,

- remaining opinions were dispersed and concerned technical knowledge, the use of tools, work organization and decisiveness.

Question 12 referred to the answers to question 11 and asked if the respondent would be willing to apply these patterns for themselves. $81.5 \%$ declared that they would apply these standards.

Question 13 asked the respondents what they observed outside the project team that was worth borrowing (the way of working, communication, type of planning, etc.). Obtained answers were grouped into four thematic groups:

- $33 \%$ reported communication issues,

- $30 \%$ indicated that there was nothing to imitate in other teams,

- $11 \%$ chose issues related to work planning,

- remaining opinions were dispersed and concerned technical knowledge, the use of tools, work organization, self-control, motivation.

From the answers obtained in survey in question 14 it can be concluded that $77.8 \%$ of respondents would be willing to implement the patterns observed outside the team.

\section{SUMMARY OF THE RESULTS OF CONDUCTED SURVEY}

Summarizing the results of survey conducted among the project team members, the following conclusions can be drawn:

- The vast majority of respondents know what projects they are involved in, what their role is and to whom the data they are working on are useful.

- The answers did not indicate one strong factor helping the engineers in the implementation of project tasks. The highest rating of $22.2 \%$ was given to management support. This may point to the problem of insufficient involvement of the management, as seen by project team members who feel left on their own, and only in emergency situations do superiors come to the fore, saving the specialist from oppression. This naturally evokes a feeling of gratitude.

- When asked what the respondents could imitate from other teams, the issue of communication was mentioned first. Approximately 33\% of respondents suggest that they are not satisfied with their own team. If we combine this with answers to questions about what they could learn from their teammates, $22 \%$ of respondents do not see such areas. This gives an impression of loneliness at work, combined with competition within the project team. The question immediately arises whether the respondents participated in lessons learned in other projects and whether the management is interested in this problem. This image is supplemented by the answers given in questions 4, 6 and 10, which show that communication problems with other team members make it more difficult for the respondents to work. 
The survey results show that one of the key issues requiring improvement during production implementations is not the knowledge of specialists, problems with machinery or plant equipment, but the increase in specialists' and managers' ability to effectively communicate and cooperate. This shows how important is the problem of risk assessment related to the project team for the project within quality planning. According to the authors, the new model of project plan should be enriched with the risk assessment related to communication in the project team, within the feasibility assessment of the whole project. The risk assessment would take place at the start of project and then three times after the milestones of this project. More on this subject in the PhD thesis by A. Górniak (Górniak, 2019).

\section{REFEENCES}

Chrysler Corporation, Ford Motor Company, General Motors Corporation. (2008). Advanced Product Quality Planning (APQP) and Control Plan. 2. Southfield: AIAG, 1.

Cole, G. A. (1994). Strategie Zarządzania. Londyn: DP Publications.

Górniak, A. (2019) . Wykorzystanie wybranych środków i sposobów pozyskiwania i przetwarzania danych dla potrzeb wyprzedzającego planowania jakości z uwzględnieniem potrzeb klienta, jako elementu przygotowania produkcji na przykładzie wybranej branży. Praca doktorska, Zabrze: Politechnika Śląska.

Górniak, A. and Każmierczak, J., (2017). Problematyka wyprzedzającego planowania jakości wyrobu i procesu na przykładzie branży automotiv. Zakopane: XX Konferencja Innowacje w Zarządzaniu i Inżynierii Produkcji.

Grudzewski, M. (2004). Metody projektowania systemów zarządzania. Warszawa: Difin.

Karaszewski, R. and Skrzypczyńska, K. (2013). Zarządzanie Jakością. Toruń: Wyd. Dom Organizatora.

Kaźmierczak, J., Midor, K. and Górniak, A., (2018). Advantages and disadvantages of using methane from CNG in motor vehicles in polish conditions. Multidisciplinary Aspects of Production Engineering - MAPE, 1. Zawiercie: Panova.

Klincewicz, K. (2016). Zarządzanie, organizacje i organizowanie - przegląd perspektyw teoretycznych. Warszawa: Wydawnictwo Naukowe Wydziału Zarządzania Uniwersytetu Warszawskiego.

Matuszak, A. and Matuszak, Z. (2011). Określenie próby i jej liczności w badaniach pedagogicznych. General and Professional Education, 2, pp. 2084-1469.

Midor, K. and Horodecka, A. (2017). Doskonalenie produktów poprzez poprawę jakości życia pracowników z wykorzystaniem nowych technologii. Systemy Wspomagania w Inżynierii Produkcji, 5(6).

Molenda, M. and Ratman-Kłosińska, I. (2018). Quality assurance in environmental technology verification (ETV): Analysis and impact on the EU ETV pilot programme performance, Management Systems in Production Engineering, 26(1), pp. 49-54.

Owczarzak, W. (2016). Autobusy napędzane CNG w Polsce. Efektywność transportu, 6.

Palka, D., Brodny, J. and Stecula, K. (2017). Modern Means of Production and the Staff Awareness of the Technical in the Plant of the Mining Industry, CBU International Conference. Innovations. In: P. Hajek, O. Vit, P. Basova, M. Krijt, H. Paszekova, O. Souckova, R. Mudrik, ed., Science And Education. Book Series: CBU International Conference Proceedings, 5, pp.1190-1194. DOI: 10.12955/cbup.v5.1094.

Spałek, S., 2019. Data Analytics in Project Management. Boca Raton, FL : CRC Press/Taylor \& Francis Group, 2019. ISBN 978-1-138-30728-5.

Wojtaś-Jakubowska, A. (2018). 7 błędów komunikacji wewnętrznej w firmach. Emplo.pl. Available at: https://emplo.pl/blog/7-bledow-komunikacji-wewnetrznej-w-firmach/. [Accessed 21 Jan. 2018]. 
Abstract. The implementation of a new product in serial production is a very important element in the company's functioning. Manufacturers of cars and complex subassemblies have been working for years according to the established standards of designing and implementing new products for serial production. A great emphasis is placed here on the formal side. In addition, the supplier must prove that has sufficient resources to achieve these objectives. And this is what customers verify during system, product, process and potential audits. However, despite formal approval of parts from the supplier, as well as confirmation of design and production capabilities, defective parts or components are sometimes assembled in cars and distributed to the market. Why does this happen? The answer can often be found not in the forms, manuals or procedures, but in the way the project teams communicate and cooperate with each other and with other organizations. This is confirmed by the research results presented in this paper, which show that one of the key issues requiring improvement during production implementations is not the knowledge of specialists, problems with the machine park or plant equipment, but increasing the ability of specialists and managers to effectively communicate and cooperate. It shows how important is the problem of risk assessment related to the project team for the project within the quality planning. According to the authors, the new model of project plan should be enriched with the risk assessment related to communication in the project team, as a part of the feasibility assessment of the whole project.

Keywords: project, project team, communication, automotive industry 